Buca Eğitim Fakültesi Dergisi, 2021, say1 52, s. 692-706

Araştırma Makalesi
DERGISI
Journal of Buca Faculty of

Education, 2021, issue 52, p. 692-706

Research Article

\title{
Investigation of the Effect of Peer Awareness Training Activity on Internet Addiction and Cyberbullying Level
}

\section{Akran Farkındalığı Eğitiminin İnternet Bağımlılığı ve Siber Zorbalık Düzeyine Etkisinin İncelenmesi}

\author{
Nükhet HOTAR ${ }^{l}$, Kadir DEMIR ${ }^{2}$, Zekavet KABASAKAL ${ }^{3}$, Medine YILMAZ4, \\ Emel KURUOĞLU KANDEMIR ${ }^{5}$, Gülçin UYANIK ${ }^{6}$, Orkide BAKALIM ${ }^{7}$, \\ Ísmail CANOĞLU ${ }^{8}$, Tolga GÜNVAR ${ }^{9}$, Pinar SÜRAL ÖZER ${ }^{10}$
}

\begin{abstract}
IProf. Dr., Dokuz Eylül University, Turkey, nukhethotar@deu.edu.tr, (https://orcid.org/00000002-2195-0852)

${ }^{2}$ Res. Asst. Dr., Department of Computer and Instructional Technology, Buca Education Faculty, Dokuz Eylül University, Turkey, kadir.demir@deu.edu.tr, (https://orcid.org/0000-0001-95689450)

${ }^{3}$ Assoc. Prof. Dr., Department of Educational Sciences, Program of Psychological Counseling and Guidance, Buca Education Faculty, Dokuz Eylül University, Turkey, zekavet.kabasakal@deu.edu.tr, (https://orcid.org/0000-0002-3450-1060)

${ }^{4}$ Prof. Dr., Department of Nursing, Program of Public Health Nursing, Faculty of Health Sciences, İzmir Katip Çelebi University, Turkey, medine.cyilmaz@ikc.edu.tr, (https://orcid.org/0000-0001-9409-6282)

${ }^{5}$ Prof. Dr., Department of Computer Sciences, Faculty of Science, Dokuz Eylül University, Turkey,emel.kuruoglu@deu.edu.tr, (https://orcid.org/0000-0003-1881-796X)

${ }^{6}$ Res. Asst. Dr., Department of Nursing, Program of Public Health Nursing, Faculty of Health Sciences, İzmir Katip Çelebi University, Turkey, gulcinyelten@hotmail.com, (https://orcid.org/0000-0002-8096-6037)

${ }^{7}$ Assoc. Prof. Dr., Department of Educational Sciences, Program of Psychological Counseling and Guidance, Faculty of Education, Izmir Demokrasi University, Turkey, orkide.bakalim@idu.edu.tr, (https://orcid.org/0000-0003-1726-0514)

${ }^{8}$ Graduate Student, Department of Computer Sciences, Institute of Science, Dokuz Eylül University, Turkey, canoglu.ismail@ogr.deu.edu.tr, (https://orcid.org/0000-0003-0904-7713)

${ }^{9}$ Assoc. Prof. Dr., Department of Medical Sciences Program of Family Medicine, Medical Faculty, Dokuz Eylül University, Turkey, tolga.gunvar@deu.edu.tr, (https://orcid.org/00000001-6700-3175)

${ }^{10}$ Prof. Dr., Department of Business Program of Management and Organization, Faculty of Economics and Administrative Sciences, Dokuz Eylül University,Turkey,pinar.ozer@deu.edu.tr, (https://orcid.org/0000-0002-8297-2772)
\end{abstract}




\begin{abstract}
Internet addiction is commonly observed in young people and it negatively affects their psychological health. In this study conducted as part of the İzmir Universities Platform Administration Era of Dokuz Eylül University (year 2019), Social Responsibility Project: Digital Citizenship: Do not Be an Addict and a Bully, Use the Internet Consciously and Safely, the effect of peer awareness training on Internet addiction among university students was examined. A total of 188 students studying in eight universities in İzmir constituted the sample of the study. The data of the study were collected via a 33-item Peer Awareness Training Knowledge Measurement Survey including socio-demographic information and information on Internet use developed by the researchers and the 12-item Short Form of Young's Internet Addiction (YIA) Test. The findings show that approximately $50 \%$ of the 188 undergraduate students had a score higher than the average score on the YIA Test and this is an indicator of addiction. A low, positive, and significant correlation was found between Internet use duration and the frequency of social media use of the students and their YIA Test scores.
\end{abstract}

Keywords: Internet addiction, cyber bullying, social media, peer training.

ÖZ

Bireylerin psikolojik sağlığını olumsuz yönde etkileyen internet bağımlılığı sıklıkla gençler arasında görülmektedir. İzmir Üniversiteleri Platformu 2019 yılı Dokuz Eylül Üniversitesi Başkanlığı Dönemi, Sosyal Sorumluluk Projesi; Dijital Vatandaşlık: Bağımlı ve Zorba Olma, İnterneti Bilinçli ve Güvenli Kullan projesi kapsamında gerçekleştirilen bu araştırmada, akran farkındalığı eğitiminin üniversite öğrencilerinin internet bağımlılığı üzerindeki etkisi incelenmiştir. Araştırmanın örneklemini İzmir'deki sekiz üniversitede eğitim öğretim gören toplam 188 öğrenci oluşturmuştur. Araştırmanın verileri, araştırmacılar tarafından geliştirilen sosyo-demografik bilgiler ve internet kullanımı ile ilgili bilgilerin alındığı 33 maddelik “Akran Farkındalığı Eğitimi” Bilgi Ölçüm Anketi ve 12 maddelik Young İnternet Bağımlılı̆̆1 Testi (YİB) - Kısa Formu ile toplanmıştır. Bulgular, 188 lisans öğrencisinin yaklaşık yüzde 50’sinin Young İnternet Bağımlılığı Testi ortalama puan üstünde olduğunu ve bu durumun bağımlılık göstergesi olduğunu göstermektedir. Öğrencilerin internet kullanım süresi ve sosyal medya kullanım sıklığ1 ile YİB ölçek puanları arasında düşük düzeyde, pozitif ve anlamlı bir ilişki bulunmuştur.

Keywords: İnternet bağımlılı̆̆ı, siber zorbalık, sosyal medya, akran eğitimi.

\title{
INTRODUCTION
}

Internet addiction can be observed in all age groups, but the most crucial risk group is young people (Gezgin \& Kaplan Akıllı, 2016; Öztürk, Odabaşığlu, Eraslan, Genç \& Kalyoncu, 2007). According to Erikson, young adulthood is the period when the individual experiences the confusion of isolation versus intimacy. This is a vital period that also includes the university years, when young people feel the need to establish close and intimate relationships most (Sternberg \& Williams, 2002). In the event that this need is not satisfied, young people may prefer an isolated life. This life-style may lead to spending more time on the Internet or even to Internet addiction. In fact, loneliness and Internet addiction are concepts that have been found to be related (Bozoğlan, Demirer \& Şahin, 2013; Caplan, 2002; Erdoğan, 2008). Internet addiction is defined as experiencing depressive emotions due to the inability of an individual to limit his or her Internet use and the disruption of the functionality of daily activities (Shapira, Goldsmith, Keck, Khosla \& McElroy, 2000). This disrupted functionality may negatively affect the psychological health of the young person.

Internet use can temporarily evoke positive emotions in young people and distract them from negative moods by separating them from reality. However, when it turns into an addiction, it can negatively affect school and social life, disrupt the emotional balance, and thus impair psycho-social development (Ayas \& Horzum, 2013; Gezgin \& Kaplan Ak1ll, 2016; Yang, Li, 
Fu \& Kou, 2016). Some research findings have shown a relationship between Internet addiction and depression (Ayas \& Horzum, 2013; Bayraktar, 2001; Ha and Hwang, 2014; Kurtaran, 2008; Yen, Ko, Yen, Chang \& Cheng, 2009), low self-esteem and life satisfaction (Ayas \& Horzum, 2013; Bozoğlan et al., 2013; Ko, Yen, Yen, Lin \& Yang, 2007; Wang et al., 2013), and low selfefficacy and increased impulsivity in young people (Ko et al., 2007; Treuer, Fabian, \& Füredi, 2001). Another concept that has been found to be closely related to Internet addiction and to threaten the psychological health of young people is cyber bullying (Chang et al., 2015; Hinduja \& Patchin, 2010).

Cyber bullying is a type of bullying that involves conscious, repeated, and hostile behaviors that are planned in order to harm other people by way of computers, mobile phones, and other electronic devices. These behaviors include sending threatening messages, making derogatory comments about the individual on social platforms or websites, and intimidating or threatening the individual online (Hinduja \& Patchin, 2010). Furthermore, actions such as reading the e-mails of others without consent, and taking embarrassing photographs of the individual without warning and disseminating them are also included within the scope of cyber bullying (Erdur Baker \& Kavşut, 2007). Even though cyber bullying behaviors are experienced in all grades starting from elementary school, findings show that these behaviors increase in parallel with age (Kiriakidis \& Kavoura, 2010). Accordingly, considering that Internet and social media use is frequent during the university years, it is thought that the tendency to be exposed to cyber bullying or being a cyber bully will be high in this period (Musharraf \& Anis-ul-Haque, 2018).

It was reported that young people who conduct activities within the scope of cyber bullying or are exposed to cyber bullying have higher rates of suicidal thoughts than those who have not experienced or demonstrated such acts (Hinduja \& Patchin, 2010; Holt et al., 2015). On the other hand, it was determined that these young people experience negative conditions more frequently such as low self-esteem (Hinduja and Patchin, 2010), clinical depression (Chang et al., 2015), academic inadequacy (Faryadi, 2011), lack of social support, and low selfefficacy (Olenik Shemesh \& Heiman, 2017). In addition, psychological symptoms such as anxiety and paranoia were also reported to be associated with cyber bullying (Schenk \& Fremouw, 2012).

Internet addiction was first included in the DSM IV diagnosis criteria (Young, 1998) and is treated in psychiatric clinics today. Moreover, it is important to raise awareness among young people before reaching the treatment stage. It is thought that it would be more effective to raise this awareness especially by peers. This is because young people are affected by their peers regarding Internet use (Esen \& Gündoğdu, 2010). Hence, it was observed that the program developed by Shek, Tang and Lo (2009,) which included a peer support group, was found beneficial by students. However, no program was found in the literature on the prevention of Internet addiction or increasing awareness on this subject by way of peer support. In the present study, the effect of the peer awareness training held by the İzmir Universities Platform on Internet addiction among university students was examined. In this context, it is thought that this study would be a pioneer for the widespread and effective prevention and awareness programs to be established throughout the country on Internet addiction and for the studies to be conducted on this issue.

\section{METHOD}

The study was carried out in a pre-test post-test single group experimental design. The present study is a part of the process conducted within the Izmir Universities Platform Administration Era of Dokuz Eylül University Social Responsibility Project: Digital Citizenship: Do Not Be an Addict and a Bully, Use the Internet Consciously and Safely. A Social Responsibility Operations Working Group; Peer Awareness Training Working Group; Digital 
Citizenship Training and Conferences Working Group; Digital Citizenship Short Film Jury; and Digital Citizenship Comics Juries were formed and continued to carry out the different steps of the project throughout the year.

The population of the study included undergraduate students studying in eight state and private universities located in Izmir. In order to ensure the participation of students from each university in the selection of samples, an announcement was made to the students and information was given about the scope of the study by an instructor who was involved as the coordinator. Thus, a total of 188 students that participated in the training themed "Internet Addiction and Cyber Bullying", which was held by the Izmir Universities Platform, and that received certificates constituted the working group of the study. All of the students answered questions before and after the training; thus, the whole of the population was reached. As data collection tools, the "Peer Awareness Training" Knowledge Measurement Survey, Pre-Test Measurement Survey, Post-Test Measurement Survey, Peer Interaction Interview Form, and the Short Form of Young's Internet Addiction Test (YIAT-SF) were used.

\subsection{Peer Awareness Training Knowledge Measurement Survey}

The questionnaire used in the pre-test and post-test was used by researchers who are experts in psychology, education and health sciences, was created by using the literature (Arcan and Yüce, 2016; Ha and Hwang, 2014; Yen et al., 2009; Yen et al., 2014, Wang et al., 2016). This survey consists of three sections. In the first section, there are a total of 10 questions concerning the socio-demographic information of the students (age, sex, place of residence for the longest period, education and employment status of parents, and income perception), average daily Internet use, and the frequency of daily social media use. In the second section, there are 33 questions concerning the communication skills of the students, the requirements for successful communication, the effects of technology addiction on health and social life, coping with Internet addiction, accessing true information on the Internet, ethical use, ensuring the safety on Internet, having knowledge on the criteria of Internet addiction, and countering cyber bullying. The questions in this section are answered with a five-point Likert scale (1-strongly disagree, 5strongly agree). The participants can take between 33 and 165 points from the survey. The survey was filled out by students twice, once before the training and once after.

\subsection{Short Form of Young's Internet Addiction Test (YIAT-SF)}

This form was developed by Young (1998) and turned into a short form by Pawlikowski et al. (2013). The form, whose Turkish version was adapted by Kutlu et al. (2016), consists of 12 items and a single dimension. The frequency of experiencing the situations in the form is recorded by giving one of five answers (1-Never, 2-Rarely, 3-Sometimes, 4-Often, 5-Always). Greater Internet addiction is shown by a higher score from the scale. The scale has no cut-off point. Cronbach's alpha coefficient of the original form was 0.85 , while the coefficient of the Turkish version was 0.91 for university students and 0.86 for adolescents (Pawlikowski et al., 2013; Kutlu et al., 2016). In the present study, Cronbach's alpha was 0.89. Students filled out the YIAT-SF once, before the training.

\subsection{Peer Awareness Training}

The project started with a call made during the first of the technology themed organizations planned in 2019, a flash mob event entitled 'Be a Digital Citizen!'; then a conference entitled 'Digital Citizenship: Do not Be an Addict and a Bully, Use the Internet Consciously and Safely' was held; and the Digital Citizenship Peer Awareness Training. The project was carried out in three phases.

1st Stage: IUP (İzmir University Platform) Peer Awareness Training Program was organized. The training in which students participated was carried out on weekends. The total number of students who participated in the training and answered pre-test and post-test questions and received certificates was 188 . The training of volunteer students who were expected to create 
peer awareness, was carried out within the scope of Internet addiction and cyber bullying themes (awareness training). Approximately 30 volunteer students were selected from eight universities from Izmir to create peer awareness. The training of volunteer peer students was carried out on October 19th-20th, 2019 for two days, for a total of 12 hours.

2nd Stage: Peer awareness interaction was carried out by 188 volunteer peer educators. In this stage, a 'Peer Interaction Interview Form' was delivered to 1721 students and analyzed. The universities of the peers contacted after the training were not only those in Izmir; a satisfaction survey was also administered to 170 students from 66 different universities (Hotar et al., 2021).

The results of the Peer Awareness Training were presented within the 3rd Stage: İzmir Universities Platform Technology Days. Furthermore, Digital Citizenship Training and Conferences were prepared by expert academic members on different subjects and presented to the students of 8 universities in 27 sessions. Digital Citizenship Short Film and Comics competitions were held and the winners received their awards after the results were announced at the Izmir Universities Platform Technology Days and the works of the contestants were exhibited during the Technology Days.

\subsection{Participants}

Data is collected from 188 students enrolled at eight different universities located in the İzmir part of Turkey. Participants were informed about the aims of the study and how to fill out the questionnaire. Then, volunteer students participated to study. Demographic information of the participants is shown in Table 1.

Table 1. Numbers of Peers Interviewed According to Universities

\begin{tabular}{lcc}
\hline University & Number of students & Percentage \\
\hline Dokuz Eylül University & 32 & 17.0 \\
Yaşar University & 24 & 12.8 \\
Kâtip Çelebi University & 28 & 14.9 \\
Demokrasi University & 29 & 15.4 \\
Ege University & 26 & 13.8 \\
İzmir Institute of Technology & 8 & 4.3 \\
Bakırçay University & 17 & 9.0 \\
Economy University & 24 & 12.8 \\
Total & 188 & 100.0 \\
\hline
\end{tabular}

Information regarding the sex, age, university type, place where they spent the last 10 years, and education and income level of the parents of the 188 students interviewed is shown in Table 2. 
Table 2. Demographic Information of the Students

\begin{tabular}{|c|c|c|}
\hline & Number of students & Percentage \\
\hline \multicolumn{3}{|l|}{$\overline{S e x}$} \\
\hline Female & 140 & 74.5 \\
\hline Male & 48 & 25.5 \\
\hline \multicolumn{3}{|l|}{ Age } \\
\hline $18-20$ years & 96 & 51.0 \\
\hline 21-24 years & 82 & 43.6 \\
\hline 25 years or above & 10 & 5.4 \\
\hline \multicolumn{3}{|l|}{ University } \\
\hline State university & 140 & 74.5 \\
\hline Private university & 48 & 25.5 \\
\hline \multicolumn{3}{|c|}{ The place where the last 10 years spent } \\
\hline Village/Town & 10 & 5.3 \\
\hline County & 46 & 24.5 \\
\hline City & 46 & 24.5 \\
\hline Metropolis & 86 & 45.7 \\
\hline \multicolumn{3}{|l|}{ Father's Education Status } \\
\hline Illiterate & 3 & 1.6 \\
\hline Literate & 5 & 2.7 \\
\hline Elementary+Secondary School & 81 & 43.1 \\
\hline High School & 52 & 27.7 \\
\hline College and University & 47 & 25 \\
\hline \multicolumn{3}{|l|}{ Mother's Education Status } \\
\hline Illiterate & 9 & 4.8 \\
\hline Literate & 15 & 8 \\
\hline Elementary+Secondary School & 87 & 46.3 \\
\hline High School & 39 & 20.7 \\
\hline College and University & 38 & 20.2 \\
\hline Illiterate & 9 & 4.8 \\
\hline \multicolumn{3}{|l|}{ Income Level } \\
\hline Very Low & 5 & 2.7 \\
\hline Low & 29 & 15.4 \\
\hline Average & 138 & 73.4 \\
\hline High & 16 & 8.5 \\
\hline Very High & 5 & 2.7 \\
\hline
\end{tabular}

\subsection{Ethical Applications}

Approval for the study was obtained from the research ethics committee (87347630/42104268/2989, dated 13.07.2020 and numbered 7) at Dokuz Eylül University. Written consent was obtained from the students that wanted to be training instructors for the study. Permission to use the scales was obtained from their authors. 


\subsection{Data Analysis}

The data were analyzed using SPSS 23.0 and $\mathrm{p}<0.05$ was considered statistically significant. Frequencies, percentage, arithmetic mean, and standard deviation were the descriptive statistics of the data used. In accordance with the central limit theorem, the t-test and one-way analysis of variance were used in the comparative analysis. The Cronbach alpha value for the data collected with the Young's Internet Addiction Test within the scope of the research is 0.89 .

\section{FINDINGS}

Table 3 includes information on the average daily Internet use duration (hours) and the frequency of daily social media use (Facebook, Twitter, Instagram, etc.) as determined by the participants themselves. The $13 \%$ who use the Internet for 6 hours or more are in the group that can be considered addicted.

Table 3. Internet and Social Media Use Duration

\begin{tabular}{lcc}
\hline & Number of students & Percentage \\
\hline Internet Use Duration (hours) & 11 & 5.9 \\
1 or less & 89 & 47.3 \\
$2-3$ & 64 & 34 \\
$4-5$ & 24 & 12.8 \\
6 or more & & 1.6 \\
Frequency of Social Media Use & 3 & 4.8 \\
Never & 9 & 23.9 YIA \\
Rarely & 45 & 52.7 \\
Sometimes & 99 & 17.0 \\
Often & 32 & \\
Always & & \\
\hline
\end{tabular}

The mean score of the 12-item Young's Internet Addiction Test of the 188 undergraduate students was $27.91( \pm 8.88)$. Table 4 shows the scores according to group and Figure 1 shows the histogram. Approximately $50 \%$ of the students are above the mean score. This is an indicator of addiction.

Table 4. Young's Internet Addiction Test Scores

\begin{tabular}{cccccc}
\hline Group & Score & $\begin{array}{c}\text { Number of } \\
\text { students }\end{array}$ & Percentile & $\begin{array}{c}\text { Cumulative Student } \\
\text { Number }\end{array}$ & $\begin{array}{c}\text { Cumulative } \\
\text { Percentage }\end{array}$ \\
1 & $14-16$ & 12 & $8 \%$ & 12 & $8 \%$ \\
2 & $17-18$ & 12 & $8 \%$ & 24 & $16 \%$ \\
3 & $19-20$ & 16 & $8 \%$ & 40 & $24 \%$ \\
4 & $21-23$ & 20 & $9 \%$ & 60 & $33 \%$ \\
5 & $24-25$ & 15 & $9 \%$ & 75 & $42 \%$ \\
6 & $26-27$ & 22 & $9 \%$ & 97 & $51 \%$ \\
7 & $28-29$ & 10 & $11 \%$ & 117 & $62 \%$ \\
8 & $30-31$ & 22 & $12 \%$ & 139 & $74 \%$ \\
9 & $32-39$ & 26 & $13 \%$ & 165 & $87 \%$ \\
10 & $40-48$ & 15 & $13 \%$ & 180 & $96 \%$ \\
11 & $49-54$ & 8 & $4 \%$ & 188 & $100 \%$ \\
\hline
\end{tabular}

Before starting the Internet addiction analysis, 3 participants were excluded from the study because the test data of these participants was partially incomplete in the analysis performed on the data. The study was continued with 185 people. The statistics related to the Internet addiction variable in the study are shown in Table 5. 
Table 5. Statistics Related to the Internet Addiction Variable

\begin{tabular}{lllll}
\hline & Mean & SS & Skewness & Kurtosis \\
\hline Internet Addiction & 27.89 & 8.74 & 0.81 & 0.32 \\
\hline
\end{tabular}

The histogram and normality curve for the Internet addiction variable are shown in Figure 1.

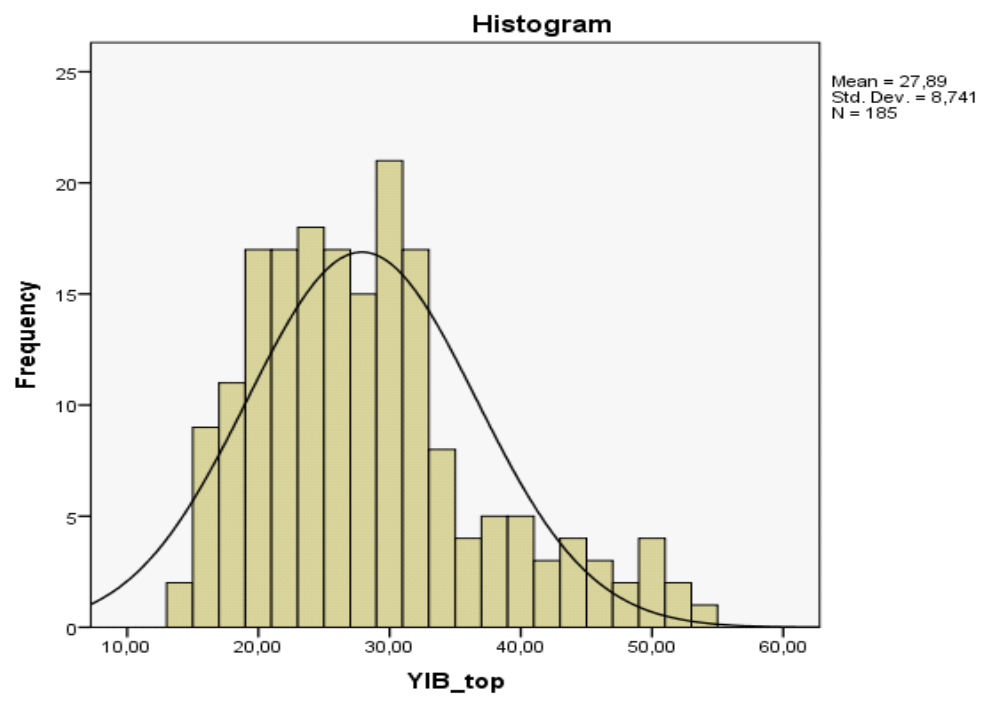

Figure 1. Histogram and Normality Curve of Young Internet Addiction Test Scores

There was no significant correlation between the YIA Test scores of students and their age groups and income levels ( $p>0.05$ ). A low, positive, and significant relation was found between the Internet use duration of the students and YIA Test scores $(\mathrm{r}=0.212, \mathrm{p}<0.01)$. A low, positive, and significant relation was also found between the frequency of social media use of students and YIA Test scores $(\mathrm{r}=0.238, \mathrm{p}<0.001)$.

No significant relation was found between the YIA Test scores according to the sex of the students. It was determined that the YIA Test scores showed a significant difference according to the daily Internet use of the students and that the mean scores of the YIA Test of those using the Internet 4-5 hours $(\mathrm{p}=0.05)$ and 6 hours or more per day $(\mathrm{p}=0.05)$ were higher than those who used it for other durations $(\mathrm{p}=0.05)$. No significant difference was found between the social media use frequency of the students and the YIA Test scores. However, it was determined that the YIA Test scores increased as the frequency of use did. The results of the survey are shown in Table 6.

Table 6. Comparison of YIA Test Scores According to Some Characteristics of Students ( $\mathrm{n}=$ 185)

\begin{tabular}{llll}
\hline & $\mathrm{n}(\%)$ & IAS Score $(\mathrm{X} \pm \mathrm{SD})$ & $\mathrm{Test}, \mathrm{p}$ \\
\hline Sex & & & \\
Female & $137(74.0)$ & $27.55 \pm 8.74$ & ${ }^{\mathrm{a}} \mathrm{t}=-0.872$ \\
Male & $48(26.0)$ & $28.83 \pm 8.78$ & $\mathrm{p}=0.385$ \\
\hline Daily Internet use duration & & & \\
1 hour or less or non-user & $11(5.95)$ & $20.55 \pm 6.56$ & \\
2-3 hours & $87(47.02)$ & $27.61 \pm 8.83$ & \\
4-5 hours* & $64(34.59)$ & $28.42 \pm 7.94$ & $\mathrm{p}=0.05$ \\
6 hours or more* & $23(12.43)$ & $30.96 \pm 9.82$ & \\
\hline
\end{tabular}




\begin{tabular}{llll}
\hline IAS scores according to the frequency of social media & & & \\
use & $3(1.62)$ & $18.6667 \pm 4.73$ & \\
Never & $8(4.32)$ & $22.2500 \pm 5.34$ & \\
Rarely & $45(24.32)$ & $25.8889 \pm 7.92$ & $\mathrm{~b}=3.092$ \\
Sometimes & $98(52.97)$ & $28.9898 \pm 9.28$ & $\mathrm{p}=0.017$ \\
Often & $31(16.76)$ & $29.6452 \pm 7.74$ & \\
Always & & & \\
${ }^{a} t=$ Independent Samples T Test & & & \\
${ }^{b} F=$ One Way ANOVA & & &
\end{tabular}

The Peer Awareness Training Knowledge Measurement Survey was applied before and after the training. The results of the survey are shown in Table 7. It was determined that there was a significant increase in the Peer Awareness Training Knowledge Measurement Survey scores of the students after the training compared to the pre-test results $(\mathrm{t}(184)=-23.078, \mathrm{p}<0.001)$.

Table 7. The t-Test Results of Pre-test and Post-test Mean Scores of Peer Awareness Training Knowledge Measurement Survey

\begin{tabular}{lcccccc}
\hline Measurement & $\mathrm{N}$ & $\mathrm{X}$ & $\mathrm{SS}$ & $\mathrm{sd}$ & $\mathrm{t}$ & $\mathrm{p}$ \\
\hline Pre-test & 185 & 122.88 & 12.37 & 184 & -23.078 & .000 \\
Post-test & 185 & 142.82 & 11.81 & & & \\
\hline
\end{tabular}

When the pre-test results of the Peer Awareness Training Knowledge Measurement Survey were compared, it was found that the mean scores of the male students (126.04) were higher than those of the female students $(121.77)(t(183)=-2.076, \mathrm{p}<0.05)$. When the post-test results of the same survey were compared, it was observed that the mean scores of the male (142.00) and female (143.11) students did not differ significantly $(\mathrm{t}(183)=0.559, \mathrm{p}>0.05)$.

\section{DISCUSSION AND CONCLUSION}

The present study provides important information about Internet addiction and the importance of training within the scope of the students participating in the "Internet Addiction and Cyber Bullying" training held by the İzmir Universities Platform.

Sex is one of the most frequently used variables in studies on Internet addiction. In the present study, no significant difference was found between the Internet addiction scores of male and female students. There are different study results on this subject in the literature. A group of researchers concluded that the sexes did not differ in terms of Internet addiction, which is in line with the result of our study (A ğırtaş \& Güleç, 2020; Carbonell et al., 2012; Hills \& Argyle, 2003; Öztürk, et al., 2013), while another group of researchers obtained results showing that men had higher Internet addiction scores (Griffiths, Davies, \& Cappell, 2004; Horzum, 2011; Kanat, 2020). This finding obtained from this study may be a result of the fact that internet use is more common among young people today, regardless of male or female. In recent years, social needs for both genders such as meeting, making friends, chatting and having conversations are now met through many social platforms.

In the present study, the rate of students using social media was high (93.6\%). Similar rates were obtained in recent studies, and the rate of social media use of university students was reported to be $95.5 \%$ (Yılmaz et al., 2020) and 86\% (Kırnık, Sesam, \& Özbek, 2019). The most frequently used social media were listed as Facebook, Instagram, and Twitter. It is observed that a large proportion of university students have at least one social media account. In recent years, most socialization tools have moved to internet platforms. These platforms allow individuals to communicate with each other regardless of distance and time. Therefore, this result, which is in line with many research findings, is not surprising. 
The Internet addiction scores of the students participating in the study show a significant difference according to their daily Internet use duration. The Internet addiction scores of those who have a daily Internet use duration of 4-6 hours or more are higher. Internet use duration is considered an important criterion in addiction. Therefore, the daily Internet use durations of university students have been examined in many studies in the literature. Students with high Internet addiction scores were found to have a daily Internet use duration of 6 hours by Simkova and Cincera (2004), more than 5 hours by Ağırtaş and Güleç (2020), and 5.5 hours by Kul (2020). In non-addicts, this duration was close to 3 hours. In other studies, the results of more than 3 hours a day (Arcan \& Yüce, 2016) and between 3 and 6 hours a day (Y1lmaz et al., 2020) were obtained. This result of our study coincides with the results of the literature.

In our study, a peer awareness training knowledge measurement survey including educational attainments was used to analyze peer training. After the training, it was observed that the post-test scores of the students increased, and this increase was higher in female students. The knowledge level of male students was higher at the beginning. There are studies in the literature showing that male students have a higher knowledge level in the digital field. In a study conducted by Demir (2018), the average digital fluency of male teacher candidates was higher. In the literature, it was reported that the awareness level of female students regarding cyber bullying was higher than that of male students (Gezgin \& Çuhadar, 2012). This result can be considered to explain the high post-test scores of the female students in our study.

When the results of the study are evaluated as a whole, it is observed that the results match those in the literature and that a peer training approach is effective in increasing the knowledge level of all students in terms of the attainment of digital citizenship. A study conducted with 1644 students, who were reached by random sampling method by 188 students entitled to a certificate within Peer Awareness Training, revealed that peer training can be used as an effective method in awareness studies on Internet use (Hotar et al., 2021).

The study is limited to 188 students whose demographic information is given above in 2019. As it is known, rapid developments in technology have led technology companies to raise awareness about internet addiction and cyberbullying and take software measures. At this point, training on screen time applications and combating cyberbullying has increased.

Some suggestions were obtained with the data obtained from the research. In the prevention of Internet addiction, studies in which a peer training approach is employed can be conducted within the framework of preventive mental health studies. The study can be repeated in collaboration with larger groups and student communities. Organizing training on safe Internet use starting from lower education levels may help to reduce the problem of Internet addiction at university level.

\section{REFERENCES}

Ağırtaş, A., \& Güler, Ç. (2020). Sosyal medya kullanan üniversite öğrencilerinin internet bağımlılı̆̆ı ve sosyal kaygı durumlarının değerlendirilmesi. Çă̆ Üniversitesi Sosyal Bilimler Dergisi, 17(1), 76-89.

Arcan, K. \& Yüce, Ç. B. (2016). İnternet bağımlılı̆̆ı ve ilişkili psiko-sosyal değişkenler: aleksitimi açısından bir değerlendirme. Türk Psikoloji Dergisi, 31(77), 46-56.

Ayas, T., \& Horzum, M. B. (2016). İlköğretim öğrencilerinin internet bağımlılığı ve aile internet tutumu. Türk Psikolojik Danışma ve Rehberlik Dergisi, 4(39), 46-57.

Bayraktar, F. (2001). İnternet kullanımının ergen gelişimdeki rolü [Yayınlanmamış Doktora Tezi]. Ege Üniversitesi. 
Bozoglan, B., Demirer, V., \& Sahin, I. (2013). Loneliness, self-esteem, and life satisfaction as predictors of Internet addiction: A cross-sectional study among Turkish university students. Scandinavian Journal of Psychology, 54(4), 313-319. doi: 10.1111/sjop.12049

Carbonell, X., Chamarro, A., Griffiths, M., Oberst, U., Cladellas, R., \& Talarn, A. (2012). Problematic Internet and cell phone use in Spanish teenagers and young students. Anales de Psicología, 28(3), 789-796.

Caplan, S. E. (2002). Problematic Internet use and psychosocial well-being: development of a theory-based cognitive-behavioral measurement instrument. Computers in Human Behavior, 18(5), 553-575.

Chang, F. C., Chiu, C. H., Miao, N. F., Chen, P. H., Lee, C. M., Chiang, J. T., \& Pan, Y. C. (2015). The relationship between parental mediation and Internet addiction among adolescents, and the association with cyberbullying and depression. Comprehensive Psychiatry, 57, 21-28. doi: 10.1016/j.comppsych.2014.11.013

Demir, K. (2018). Öğretmen adaylarının dijital akıcılıklarının incelenmesi [Yayınlanmamış Doktora Tezi]. Anadolu Üniversitesi.

Erdoğan, Y. (2008). Exploring the relationships among Internet usage, Internet attitudes and loneliness of Turkish adolescents. Cyberpsychology: Journal of Psychosocial Research on Cyberspace, 2, 1-8.

Erdur Baker, Ö., \& Kavşut, F. (2007). Akran zorbalığının yeni yüzü: siber zorbalık. Eurasian Journal of Educational Research, 27, 31-42

Esen, B. K., \& Gündoğdu, M. (2010). The relationship between internet addiction, peer pressure and perceived social support among adolescents. The International Journal of Educational Researchers, 2(1), 29-36.

Faryadi, Q. (2011). Cyber bullying and academic performance. International Journal of Computational Engineering Research, 1(1), 23-30.

Gezgin, D. M., \& Kaplan Ak1llı, G. K. (2016). Investigation of high school students' Internet addiction in the light of various variables. Mersin Üniversitesi Eğitim Fakültesi Dergisi, 12(3), 917-931. doi: 10.17860/mersinefd.282390.

Gezgin, D. M., \& Çuhadar, C. (2012). Bilgisayar ve öğretim teknolojileri eğitimi bölümü öğrencilerinin siber zorbalığa ilişkin duyarlılık düzeylerinin incelenmesi. Eğitim Bilimleri Araştırmaları Dergisi, 2(2), 93-104.

Griffiths, M.D., Davies, M.N.O. \& Chappell, D. (2004). Demographic factors and playing variables in online computer gaming. Cyberpsychology \& Behavior, 7(4), 479-487.

Ha, Y. M., \& Hwang, W. J. (2014). Gender differences in internet addiction associated with psychological health indicators among adolescents using a national web-based survey. International Journal of Mental Health and Addiction, 12(5), 660-669. doi: 10.1007/s11469- 014-9500-7

Hills, P. \& Argyle, M. (2003). Uses of the Internet and their relationships with individual differences in personality. Computers in Human Behavior, 19(1), 59-70.

Hinduja, S \& Patchin, J.W. (2010) Bullying, cyberbullying, and suicide. Archives of Suicide Research, 14(3), 206-221, DOI: 10.1080/13811118.2010.494133

Holt, M. K., Vivolo Kantor, A. M., Polanin, J. R., Holland, K. M., DeGue, S., Matjasko, J. L., ... \& Reid, G. (2015). Bullying and suicidal ideation and behaviors: a meta-analysis. Pediatrics, 135(2), e496-e509. 
Horzum, M.B. (2011). İlköğretim öğrencilerinin bilgisayar oyunu bağımlılık düzeylerinin çeşitli değişkenlere göre incelenmesi. Eğitim ve Bilim, 36(159), 56-68.

Hotar, N., Kabasakal, Z., Uyanık, G., Yılmaz, M., Kuruoğlu Kandemir, E., Demir, K., Bakalım, O., Canoğlu, İ., Günvar, T. \& Süral Özer, P. (2021). Investigation of university students' Internet addiction levels and social media usage characteristics: A descriptive study [Unpublished manuscript].

Kanat, H. (2020). Üniversite öğrencilerinin sosyal yeterlik düzeyleri ile internet bağımlılı̆̆ arasındaki ilişkinin incelenmesi [Yayınlanmamış Yüksek Lisans Tezi]. Karabük Üniversitesi.

Kırnık, D., Susam, E., \& Özbek, R.(2019) Öğretmen adaylarının internet bağımlılık düzeyi. İnönü Üniversitesi Ĕgitim Fakültesi Dergisi, 20(3), 976-986.

Kiriakidis, S. P., \& Kavoura, A. (2010). Cyberbullying: A review of the literature on harassment through the internet and other electronic means. Family \& Community Health, 33(2), 8293.

Ko, C. H., Yen, J. Y., Yen, C. F., Lin, H. C., \& Yang, M. J. (2007). Factors predictive for incidence and remission of internet addiction in young adolescents: a prospective study. CyberPsychology \& Behavior, 10(4), 545-551. doi: 10.1089/cpb.2007.9992

Kul, S. (2020). Dijital okuryazarlık ve diğer değişkenlerle İnternet bağımlılığı ilişkisinin incelenmesi. Uluslararası Yönetim Bilişim Sistemleri ve Bilgisayar Bilimleri Dergisi, 4(1), $28-41$.

Kutlu, M., Savcı, M., Demir, Y., \& Aysan, F. (2016). Young internet bağımlılı̆̆ı testi kısa formunun türkçe uyarlaması: Üniversite öğrencileri ve ergenlerde geçerlilik ve güvenilirlik çalışması. Anadolu Psikiyatri Dergisi, 17(1), 69-76.

Kurtaran, G. T. (2008). İnternet bağımlılı̆̆ını yordayan değişkenlerin incelenmesi [Yayınlanmamış Yüksek Lisans Tezi]. Mersin Üniversitesi.

Musharraf, S., \& Anis-ul-Haque, M. (2018). Cyberbullying in different participant roles: Exploring differences in psychopathology and well-being in university students. Pakistan Journal of Medical Research, 57(1), 33-39.

Olenik Shemesh, D., \& Heiman, T. (2017). Cyberbullying victimization in adolescents as related to body esteem, social support, and social self-efficacy. The Journal of Genetic Psychology, $178(1), 28-43$.

Öztürk, O., Odabasioglu, G., Eraslan, D., Genc, Y., \& Kalyoncu, O. A. (2007). Internet addiction: Clinical aspects and treatment strategies. Bağımlılık Dergisi, 1(8), 36-41.

Öztürk, F. O., Ekinci, M., Öztürk, Ö. \& Canan, F. (2013). The relationship of affective temperament and emotional-behavioral difficulties to Internet addiction in Turkish teenagers. ISRN Psychiatry, 2013, 1-6.

Pawlikowski, M., Altstötter Gleich, C., \& Brand, M. (2013). Validation and psychometric properties of a short version of Young's Internet addiction test. Computers in Human Behavior, 29(3), 1212-1223.

Schenk, A. M., \& Fremouw, W. J. (2012). Prevalence, psychological impact, and coping of cyberbully victims among college students. Journal of School Violence, 11, 21-37. doi:10.1080/15388220.2011. 630310

Shapira, N. A., Goldsmith, T. D., Keck, P. E., Khosla, U. M., \& McElroy, S. L. (2000). Psychiatric features of individuals with problematic internet use. Journal of Affective Disorders, 57(1), 267- 272. doi: 10.1016/S0165-0327(99)00107-X 
Shek, D. T., Tang, V. M., \& Lo, C. Y. (2009). Evaluation of an Internet addiction treatment program for Chinese adolescents in Hong Kong. Adolescence, 44(174).

Simkova, B. \& Cincera, J. (2004). Internet addiction disorder and chatting in the Czech Republic, CyberPsychology \& Behavior, 7(5), 536-539.

Sternberg, R. J. \& Williams, W. M. (2002). Educational psychology. Allyn and Bacon.

Treuer, T., Fábián, Z., \& Füredi, J. (2001). Internet addiction associated with features of impulse control disorder: is it a real psychiatric disorder?. Journal of Affective Disorders, 66(2), 283.

Wang, L., Luo, J., Bai, Y., Kong, J., Luo, J., Gao, W., \& Sun, X. (2013). Internet addiction of adolescents in China: Prevalence, predictors, and association with well-being. Addiction Research \& Theory, 21(1), 62-69. doi: 10.3109/16066359.2012.690053

Yang, Y., Li, P., Fu, X., \& Kou, Y. (2016). Orientations to happiness and subjective well-being in Chinese adolescents: The roles of prosocial behavior and Internet addictive behavior. Journal of Happiness Studies, 1-16. doi: 10.1007/s10902-016-9794-1

Yen, C. F., Chou, W. J., Liu, T. L., Ko, C. H., Yang, P., \& Hu, H. F. (2014). Cyberbullying among male adolescents with attention-deficit/hyperactivity disorder: Prevalence, correlates, and association with poor mental health status. Research in Developmental Disabilities, 35(12), 3543-3553.

Young, K. S. (1998). Internet addiction: The emergence of a new clinical disorder. Cyberpsychology \& Behavior, 1(3), 237-244. doi: 10.1089/cpb.1998.1.237

Yen, C. F., Ko, C. H., Yen, J. Y., Chang, Y. P., \& Cheng, C. P. (2009). Multi-dimensional discriminative factors for Internet addiction among adolescents regarding gender and age. Psychiatry and Clinical Neurosciences, 63(3), 357-364. doi: 10.1111/j.14401819.2009.01969.x

Young, K. S. (1998). Caught in the net: how to recognize the signs of internet addiction--and a winning strategy for recovery. John Wiley \& Sons.

Yilmaz, N., Elif, K., Erdem, R., \& Alkan, A. (2020). Üniversite öğrencilerinde internet bağımlılı̆̆1 ile duygu sağırlığı ilişkisi. İktisadi İdari ve Siyasal Araştırmalar Dergisi, 5(13), 347-361.

\section{GENIŞLETILMIŞ ÖZET}

İnternet bağımlılığ 1 , her yaş grubunda görülebilecek bir bağımlılık türü olmakla birlikte en önemli risk grubu gençlerdir (Gezgin ve Kaplan-Akıllı, 2016; Öztürk, Odabaşığlu, Eraslan, Genç ve Kalyoncu, 2007). Erikson'a göre genç yetişkinlik yılları bireyin yakınlığa karşı izolasyon karmaşasını yaşadığı dönemdir. Üniversite yıllarını da içine alan bu dönem gencin yakın ve samimi ilişkiler kurmaya en fazla ihtiyaç duyduğu yaşamsal dönemdir (Sternberg ve Williams, 2002). Bu ihtiyaç karşılanmadığı takdirde, genç izole bir yaşamı tercih edebilir. Bu yaşam tarzı internet başında daha fazla zaman geçirmeye hatta internet bağımlılığına neden olabilir. Nitekim yalnızlık duygusu ve internet bağımlılı̆̆ 1 ilişkili bulunan kavramlardır (Bozoğlan, Demirer ve Şahin, 2013; Caplan, 2002; Erdoğan, 2008). İnternet bağımlılı̆̆1, kişinin internet kullanımını denetleyememesi sonucu bunaltıcı duyguların yaşanması ve günlük aktivitelerindeki işlevselliğin bozulması olarak tanımlanır (Shapira, Goldsmith, Keck, Khosla, ve McElroy, 2000). Bozulan bu işlevsellik gencin psikolojik sağlı̆̆ını da olumsuz şekilde etkileyebilmektedir. 
İnternet kullanımı, gençlerde geçici olarak olumlu duygular uyandırabilir ve onları gerçeklerden kopararak olumsuz ruh hâlinden bir süreliğine uzaklaştırabilir. Oysa zamanla artan kullanım, bağımlılığa dönüştüğünde okul ve sosyal yaşamı olumsuz yönde etkileyebilmekte, duygusal dengeyi bozabilmekte dolayısıyla psiko-sosyal gelişime zarar verebilmektedir (Ayas ve Horzum, 2013; Gezgin ve Kaplan-Ak1ll1, 2016; Yang, Li, Fu ve Kou, 2016). Nitekim bazı araştırma bulguları gençlerde internet bağımlılı̆̆ ile depresyon (Ayas ve Horzum, 2013; Bayraktar, 2001; Ha ve Hwang, 2014; Kurtaran, 2008; Yen, Ko, Yen, Chang ve Cheng, 2009), düşük benlik saygısı ve yaşam doyumu (Ayas ve Horzum, 2013; Bozoğlan ve diğ., 2013; Ko, Yen, Yen, Lin ve Yang, 2007; Wang ve diğ.,2013); düşük özyeterlik ve dürtüsellikte artış (Ko ve diğ.,2007; Treuer, Fabian ve Füredi, 2001) arasında ilişki olduğunu göstermiştir.

İnternet bağımlılığı ilk kez DSM IV tanı kriterleri arasında yer almıştır (Young, 1998) ve günümüzde psikiyatri kliniklerinde tedavi edilmektedir. Bununla birlikte, tedavi aşamasına gelmeden gençlere internet bağımlılı̆̆ 1 konusunda farkındalık kazandırmak çok önemli bir basamaktır. Özellikle bu farkındalığın akranlar tarafından kazandırılmasının daha etkili olabileceği düşünülmektedir. Çünkü gençler internet kullanımı konusunda akranlarından etkilenmektedirler (Esen ve Gündoğdu, 2010). Nitekim; Shek, Tang ve Lo (2009) tarafindan geliştirilen ve içerisinde akran destek grubu içeren programın gençler tarafından faydalı bulunduğu görülmüştür. Buna karşın alanyazında internet bağımlılığını önleme ya da bu konuda farkındalık kazandırmada akran desteğini içeren programa rastlanamamıştır. $\mathrm{Bu}$ araştırma kapsamında İzmir Üniversiteleri Platformu tarafından düzenlenen akran farkındalığı eğitiminin üniversite öğrencilerinin internet bağımlılığı üzerindeki etkisi incelenmiştir. $\mathrm{Bu}$ anlamda çalışmanın internet bağımlılığına yönelik ülke genelinde geliştirilecek yaygın ve etkili önleme ve farkındalık programlarının oluşturulması ve bu konuda yapılacak olan araştırmalara öncülük edeceği düşünülmektedir.

Bu araştırma İzmir Üniversiteleri Platformu 2019 Dokuz Eylül Üniversitesi Başkanlığı Dönemi, Sosyal Sorumluluk Projesi; Dijital Vatandaşlık: Bağımlı ve Zorba Olma, İnterneti Bilinçli ve Güvenli Kullan projesi kapsamında gerçekleştirilen bir sürecin parçasıdır. Araştırmanın evreni İzmir'de bulunan sekiz devlet ve vakıf üniversitesinde eğitim gören lisans öğrencilerinden oluşmuştur. Örneklem seçiminde her üniversiteden öğrenci katılımını sağlamak amacıyla koordinatör olarak rol alan bir öğretim elemanı yoluyla öğrencilere duyuru yapılmış, çalışma kapsamı hakkında bilgi verilmiştir. Bu doğrultuda İzmir Üniversiteleri Platformu tarafından düzenlenen "İnternet Bağımlılığı ve Siber Zorbalık” temalı eğitime katılan ve sertifika alan toplam 188 öğrenci araştırmanın çalışma grubunu oluşturmaktadır. Öğrencilerin tümü eğitim öncesi ve sonrası ön test ve son test sorularına yanıt vermiş, evrenin tamamına ulaşılmıştır. Veri toplama aracı olarak “Akran Farkındalığı Eğitimi” Bilgi Ölçüm Anketi, Ön Test Ölçüm Anketi, Son Test Ölçüm Anketi, Akran Etkileşimi Görüşme Formu, Young İnternet Bağımlılı̆̆ 1 Testi Kısa Formu (YİBT-KF) kullanılmıştır. Verilerin analizi SPSS 25.0 programında yapılmış, \%95 güven aralığında $\mathrm{p}<0.05$ istatistiksel olarak anlamlı kabul edilmiştir. Verilerin tanımlayıcı istatistiklerinde frekanslar, yüzde, aritmetik ortalama ve standart sapma kullanılmıştır. Merkezi limit teoremi gereğince karşılaş̧tırmalı analizlerde $\mathrm{t}$ testi ve tek yönlü varyans analizi kullanılmıştır.

Öğrencilerin yaş grupları ve gelir düzeylerine göre YİB ölçek puanları arasında anlamlı bir korelasyon yoktur $(\mathrm{p}>0,05)$. Öğrencilerin internet kullanım süresi ile YİB ölçek puanları arasında düşük düzeyde, pozitif ve anlamlı bir ilişki bulunmuştur $(\mathrm{r}=0.212, \mathrm{p}<.01)$. Öğrencilerin sosyal medya kullanım sıklığı ile YİB ölçek puanları arasında düşük düzeyde, pozitif ve anlamlı bir ilişki bulunmuştur $(\mathrm{r}=0.238, \mathrm{p}<.001)$.

Öğrencilerin cinsiyete göre YİB ölçek puanları arasında anlamlı bir fark bulunamamıştır. Öğrencilerin günlük internet kullanım sürelerine göre YİB ölçek puanlarının anlamlı bir farklılık gösterdiği, günlük 4-5 saat $(\mathrm{p}=0,05)$ ve 6 saat/üzeri $(\mathrm{p}=0,05)$ kullananların YİB ölçek puan ortalamalarının diğer saatlerde kullananlara göre daha fazla olduğu belirlenmiştir $(p=0,05)$. Öğrencilerin sosyal medya kullanım sıklıkları ile YİB ölçek puanları arasında anlamlı bir fark 
bulunamamıştır. Ancak, kullanım sıklığı arttıkça YİB ölçek puanlarını arttı̆̆ı tespit edilmiştir. Öğrencilerin eğitim sonrasında Akran Farkındalığ1 Eğitimi Bilgi Ölçüm Anketi puanlarında ön test sonuçlarına göre anlamlı bir artış olduğu belirlenmiştir $(\mathrm{t}(184)=-23.078, \mathrm{p}<.001)$. Akran Farkındalığı Eğitimi Bilgi Ölçüm Anketi ön test sonuçları karşılaş̧ırıldığında erkek öğrencilerin ortalama puanlarının $(126,04)$, kız öğrencilerin ortalama puanlarına $(121,77)$ göre daha yüksek olduğu belirlenmiştir $(\mathrm{t}(183)=-2.076, \mathrm{p}<.05)$. Akran Farkındalığı Eğitimi Bilgi Ölçüm Anketi son test sonuçları karşılaştırıldığında erkek $(142,00)$ ve kız öğrencilerin $(143,11)$ ortalama puanlarının farkl1lık göstermediği görülmüsştür $(\mathrm{t}(183)=0.559, \mathrm{p}>.05)$.

Araştırma sonuçları genel olarak değerlendirildiğinde alanyazın ile örtüşen sonuçların elde edildiği, dijital vatandaşlık kazanımları açısından akran eğitimi yaklaşımının tüm öğrencilerin bilgi düzeyini arttırmada etkili olduğu görülmektedir. Akran Farkındalığı Eğitimi kapsamında sertifika almaya hak kazanmış 188 öğrencinin rastgele örnekleme yöntemi ile ulaştı̆̆ 1644 öğrenci ile gerçekleştirilen çalışmada Akran Eğitimlerinin internet kullanımı konusundaki farkındalık çalışmalarında etkili bir yöntem olarak kullanılabileceğini göstermiştir (Hotar ve diğ., 2021). 